the proposed atlas as they became available was generally supported. Inquiries and suggestions concerning this project should be addressed to Professor Th. Monod (Directeur, I.F.A.N., Dakar, A.O.F.).

Following the working meetings at Ibadan, the Conference moved to Jos in Northern Nigeria, from which field parties of the several sections were able, thanks to the admirable preparations organized by Mr. Bernard Fagg, Antiquities Officer of the Government of Nigeria, to visit, during three days, a number of sites and installations of special interest. The Human Sciences party, for which a field camp was provided at Nok in South Zaria Province, was able to study the stratigraphy and latest finds of both palaeolithic and prehistoric figurine cultures on the Plateau, to make an ethnographic reconnaissance among the Kaleri and Jaba, and to have demonstrated the existence of figure carving and masked dances of men's associations among these Northern peoples. Opportunity was also provided during the Conference for visits to the Nigerian Agricultural Headquarters, Moor Plantation near Ibadan, to Ife in Northern Oyo Division, the traditional centre of the Yoruba people, and to various places of interest in and around Ibadan.

The success of the Conference, as delegates fully recognized, was largely due to the untiring efforts of Mr. K. C. Murray, Mr. B. Fagg, and other members of the Local Organizing Committee in securing accommodation, transport and other facilities, and in organizing the programme.

\title{
Philosophical Society of the Sudan
}

THE society, which was founded in 1946 , to promote discussion and research in moral, political, and natural philosophy, has held twenty-one meetings and four field days during the sessions 1946-7 and 1947-8. Among the papers read was one by Mr. A. J. Arkell on 'Suggestions for lines of research in the Sudan', one by Dr. D. Dunham on 'The history of the Sudan from 800 B.C.-A.D. 350 as disclosed by excavation '; other subjects discussed included forestry research, archaeological excavation at Khartoum, climate and building design, and the development of communications. It is intended that the Proceedings of the Society shall eventually be published in a permanent form; meanwhile abridged proceedings containing abstracts of papers delivered are published annually.

\section{Phelps-Stokes Fund}

THE thirty-five year report of the Phelps-Stokes Fund, published in $1948,{ }^{1}$ includes an historical account of the development of the work of the Fund, and sketches of outstanding personalities in the Fund's history, notably the founder, Miss Caroline Phelps-Stokes.

In accordance with the wishes of the founder, the Fund's principal activities have been in the field of education and have been directed both to developing education for negroes in the United States and in Africa and to stimulating the study of the negro and his needs. Ancillary to these main purposes, the Fund has assisted the development of the South African Institute of Race Relations, has worked for the improvement of negro housing conditions in New York, and has organized and stimulated various movements in the interests of negro progress both in Africa and the United States.

One chapter of the report describes the special contributions made by Dr. Jesse Jones to the policy of the Fund, in particular his insistence on the necessity for acquiring a thorough factual basis before attempting the solution of any problem, and his conviction of the importance of inter-racial co-operation and of the special significance of rural life and agriculture.

I Negro Status and Race Relations in the United States, Phelps-Stokes Fund, N.Y., 1948, pp. 219, index. \$1.5O. 
An account of the progress of negro status during the past thirty-five years gives statistics relating to educational, economic, and religious progress in the U.S.A., and refers to improvements in the status and conditions of Africans in colonial territories in Africa; the special factors which have been mainly operative in recent developments are analysed under the categories of action by Governments, Educational Institutions, Foundations, Churches, Negro Service Associations, Publications, and Press. The chief obstacles in the way of further progress are described as ignorance on the part of whites, and extreme racism-both white and negro.

A section on the Racial Situation in Bantu Africa is contributed by Senator Rheinallt Jones.

\section{International Conferences on Land Problems in Africa}

Two conferences were held at Jos, Nigeria, in November 1949 , one to discuss land utilization and one concerned with indigenous rural economy. The first was a British conference under the Chairmanship of the Assistant Under-Secretary of State for the Colonies, at which representatives of France, Belgium, Portugal, the Union of South Africa, the United States, Southern Rhodesia, Anglo-Egyptian Sudan, and the Food and Agricultural Organization of the United Nations, were present as observers. The conference appointed five committees, whose findings were discussed at a plenary session; the systematic survey of soils in development areas was recommended, as well as the introduction of advanced methods of agriculture, and the formation of groups of peasant farmers to be established on unoccupied land under conditions favourable to the practice of good husbandry.

The International Conference on Indigenous Rural Economy was organized jointly by the United Kingdom, France, Belgium, Portugal, the Union of South Africa, and Southern Rhodesia. It recommended the wider dissemination and exchange of information on such subjects as water control, methods of food storage, processing of products within village communities, use of mechanical implements and artificial fertilizers, and the breeding of suitable grass strains. It also advocated the establishment of co-operative societies, and the emphasizing of crafts, industries, and agriculture in schools' curricula, and recorded the need for mote research in the field of microbiology.

\section{Semaines Sociales de France}

LA XXXVII ${ }^{e}$ Semaine Sociale se tiendrait à Nantes du mardi i 8 au dimanche 23 juillet. Elle traitera du 'Monde rural dans l'économie moderne'. Pour tous renseignements, s'adresser au Secrétariat Général des Semaines Sociales, I6 rue du Plat, Lyon 2, France.

\section{East African Institute of Social Studies, Makerere, Uganda}

Dr. Audrey I. Richards, M.A., Ph.D., Reader in Anthropology at the University of London and a senior member of the staff of the London School of Economics, has accepted the post of Director of the East African Institute of Social Studies and has recently taken up residence at Makerere.

Members of the Institute and readers of this journal will be well acquainted with Dr. Richards' gifts and attainments and her lively interest in African affairs. We are happy to record our appreciation of the many services she has rendered to this Institute as member of its Executive Council and of the Ethnographic Survey Committee, as contributor to Africa, and as a friend and supporter of long standing. Our good wishes for her success in this important post go with her. 